\title{
Actors' roles and functions in the improved rice varieties innovation system in the eastern zone of Tanzania
}

Charles S. ${ }^{1}$, Mattee A.Z. ${ }^{2}$ and Msuya C.P. ${ }^{3}$

Corresponding author: C.P. Msuya. Email: cat_msuya@yahoo.com

\begin{abstract}
The objective of the study was to establish the actors' roles and functions in improved rice varieties innovation system in the Eastern Zone of Tanzania. The target population samples for the study comprised of household heads $(n=340)$ and other key identified actors $(n=99)$. The research design was a convergent parallel mixed method. Face-to-face interviews, focus group discussions and documentary review were used to collect the data. The findings indicate weak or inability of Agricultural Seed Agency, TANSEED International Ltd, Quality Declared Seed producers in seed multiplication and distribution and agro-dealers were not selling quality rice seeds, thereby resulting in low availability and high prices of the same. Also, the findings show weak participation of farmers, agro- dealers, traders and millers in the functions of guidance of the search and rice varieties development, and the limited number of market actors and weak credit mobilization for farmers to invest in IRVs. The study recommends for the Government of Tanzania to create enabling environment that enhances participation of all key actors in the processes of guidance of the search and rice varieties development; linking farmers with external markets; and enhancing the farmers' access to credit facilities by working on the obstacles hampering farmers from accessing loans from financial institutions.
\end{abstract}

Key words: Innovation, innovation system, improved rice varieties innovation system, actors and functions

\section{INTRODUCTION}

Over the last three decades, there has been an increasing recognition in science and policy communities that innovation can be better understood as the outcome of an innovation system (IS). Innovation system is defined as a set of interrelated actors, their interactions, and the institutions that condition their behaviour with respect to the common objective of generating, diffusing, and utilizing knowledge (Spielman, 2005; Asenso-okyere, Davis and Aredo, 2008).

\footnotetext{
${ }^{1}$ Assistant Lecturer, Department of Agricultural Extension and Community Development, College of Agriculture, Sokoine University of Agriculture, P.O Box 3002 Morogoro, Telephone, Email: Email: jibunge@yahoo.co.uk, jibunges@gmail.com, Cellphone number: +255 715934443.

2 Associate professor, College of Agriculture, Department of Agricultural Extension and Community Development, Sokoine University of Agriculture, P.O Box 3002, Morogoro, Tanzania. CelIphone +255 787645330. Email: azmattee2009@yahoo.com, Cellphone +255 754380474

3 Associate professor, College of Agriculture, Department of Agricultural Extension and Community Development, Sokoine University of Agriculture, P.O Box 3002, Morogoro, Tanzania. CelIphone +255 787645330. Email: cat_msuya@yahoo.com and cat_msuya@sua.ac.tz Cellphone +255 787645330
} 
In this connection, the term innovation started to be defined as the economically successful use of invention or new knowledge (research outcome) that enhances social and economic change (Fagerberg, Mowery and Nelson, 2005). Equally, innovation in this study is referred to the improved rice varieties (IRVs) which have a higher yield per hectare compared to local varieties. Hence, there has been a consensus among innovation scholars that innovation in agriculture is a crucial ingredient for economic growth and development (Intarakumnerd and Chaminade, 2007, Larsen, Kim and Theus, 2009; Szogs, Cummings and Chaminade, 2011; Swedish International Development Agenc-Sida, 2015).

In this connection, since the early 2000s, Sub-Saharan African countries started paying closer attention to IS to speed up the process of agricultural growth and development (Juma, 2011; Rwambali, 2012). In Tanzania, in particular, the IS perspective has been anchored in the National Agricultural Policy-NAP (United Republic of Tanzania-URT, 2013), the National Rice Development Strategy - NRDS (URT, 2009), and the Agricultural Sector Development Programme (ASDP) II 2016/2017 - 2024/2025 (URT, 2016). Consequently, these policies align with the aspiration of the Tanzania Development Vision (TDV) 2025. The TDV 2025 aims at achieving a high quality livelihood for Tanzanian people by transforming the economy from a predominantly low productive agriculture-dependent economy to a diversified and semi-industrialized economy that ensures food security and food self-sufficiency (URT, 1999).

One of the first priority categories of food crops targeted for transformation from subsistence farming towards commercialization and modernization in Tanzania is rice. Currently, rice is the third most important food crop after maize and cassava (Wilson and Lewis, 2015). Equally, it is the second most widely produced cereal crop in Tanzania after maize with over 1.68 million growers, 1.59 million of them being on the Mainland Tanzania and 79,736 in Zanzibar (United States Department of Agriculture-USDA, 2019). However, yields are still generally very low ranging from 1 to 1.5 tons/hectare (System of Rice Intensification (SRI) - Tanzania, 2019). With this regard, Tanzania acknowledges increased use of IRVs under IS framework is a crucial ingredient for improving rice farmers' income and increasing country self-sufficient rice productivity. In 2009, the Tanzania Government formulated the NRDS as one of the instruments of meeting the objective of the TDV 2025 that aimed at transforming the existing subsistence-dominated rice sector progressively into commercially profitable and viable production system by utilizing rice innovations including IRVs (URT, 2009).

The NRDS promotes the use of IS approach by encouraging various actors to participate in the IRVs generation, multiplication, dissemination, and utilization. However, a crucial issue that very little is known about is the system structure, particularly the actors and the functional elements of the IS of IRVs. Since the inception of the IS approach, few studies have been conducted to assess its functioning in Tanzania. Such studies include Maerere, Rweyemamu, Sibuga, Mgembe, Rwambali, and Nchimbi-msolla (2010) and Rwambali (2012) on the banana ISs, Mgumia (2015) in the applications of the agricultural innovation system in the national agricultural research system and Mkula (2018) on sugarcane innovation system. There is, 
therefore, still a critical knowledge gap in understanding the functioning of improved rice varieties innovation system (IRVIS) in Tanzania. Identifying the key actors and their roles that enable a number of crucial system processes (or functions) which are necessary for the IS to perform is also crucial for effective implementation of the TDV 2025, ASDP II and NRDS aim of improving rice productivity, farmers' income and bridging the gap of rice self-sufficiency (URT, 2009).

\section{THEORETICAL FRAMEWORK}

This study was based on the Technological Innovation System (TIS) framework. A TIS can be defined as a system structure of actors and their roles, networks and institutions, which actively contribute to the development, dissemination and exploitation of a particular technology (Ecuru, 2013; Bergek, Hekkert, Jacobsson, Markard, Sandén and Truffer, 2015). It is usually used to explain the emergence, growth, and diffusion of technology in a community (Hekkert, Suurs, Negro, Kuhlmann and Smits 2007). Rwambali (2012) argues that when ISs are studied at a national level, the dynamics are difficult to map because the national innovation system (NIS) consists of many actors, networks, relations, and complex institutional set-up. For this reason, one is compelled to focus on the structure instead of mapping the processes. Therefore, IS studies (Hekkert et al., 2007; Wieczorek and Hekkert, 2012; Rwambali, 2012) have recommended TIS as the most appropriate IS framework of mapping both structure and functions that influence the development, diffusion, and utilization of a particular technology. This is because TIS is more specific in scope than NIS and sectoral innovation systems and it is the most dynamic IS approach that helps to capture the processes which really take place inside the network.

The TIS approach adopted in this paper is based on the framework suggested by Hekkert et al. (2007). Based on the different categories of functions and several empirical studies at Utrecht University, Hekkert et al. (2007) developed seven functions, which need to be present in ISs for successful innovation to occur (Table 1). The execution of these seven functions is dependent on structural components of the system in which the technology is embedded (Turner, Klerkx, Rijswijk, Williams and Barnard, 2015) especially actors in the case of this study. For example, a precondition for IRVs diffusion is the presence and interactions of actors. The reasons why a certain system function is absent or weak can be related to the structure of the IS and more specifically to the actors. In this respect, structure and functions are two intertwined sides of the same coin, the system (Wieczorek and Hekkert, 2012).

Table 1 Functions that influence the development of a particular technology

\begin{tabular}{|l|l|}
\hline Key Function & Description \\
\hline $\begin{array}{l}\text { Knowledge } \\
\text { development }\end{array}$ & $\begin{array}{l}\text { The ability to develop new knowledge through formal research or } \\
\text { farmers. The activities include generation of IRVs as new knowledge. }\end{array}$ \\
\hline $\begin{array}{l}\text { Entrepreneurial } \\
\text { activities }\end{array}$ & $\begin{array}{l}\text { Turn the new knowledge into business opportunities to realise social } \\
\text { and economic value. }\end{array}$ \\
\hline
\end{tabular}




\begin{tabular}{|l|l|}
\hline $\begin{array}{l}\text { Knowledge } \\
\text { diffusion/ } \\
\text { exchange (through } \\
\text { networks) }\end{array}$ & $\begin{array}{l}\text { Processes and activities that focus on information dissemination, } \\
\text { awareness raising and capacity-sharing and resource sharing among } \\
\text { system actors. The processes or activities include conferences, } \\
\text { seminars, workshops, leaflets and brochures. }\end{array}$ \\
\hline Guidance of search & $\begin{array}{l}\text { Activities and processes within an IS that can affect the visibility and } \\
\text { usability of a specific innovation according to actors' expectations, } \\
\text { articulated user demand and societal discourse. Through interactive } \\
\text { and cumulative process of exchanging ideas among actors in the } \\
\text { system, innovations get continuously modified. }\end{array}$ \\
\hline Market formation & $\begin{array}{l}\text { Creation of markets for new technologies (produce of IRVs). The types } \\
\text { of rice markets available (formal or informal markets, rice price etc.) } \\
\text { in the study area. }\end{array}$ \\
\hline $\begin{array}{l}\text { Resource } \\
\text { mobilization }\end{array}$ & $\begin{array}{l}\text { Involves the basic financial, physical, and human capital as necessary } \\
\text { basic inputs for all processes in the ISs. This function distributes the } \\
\text { necessary resources for the development and diffusion of new } \\
\text { technologies among actors of the innovation system. }\end{array}$ \\
\hline $\begin{array}{l}\text { Creation of } \\
\text { legitimacy for } \\
\text { change }\end{array}$ & $\begin{array}{l}\text { This function carries out activities that provide legitimacy for new } \\
\text { technologies. This study mapped the actors involved in this activity } \\
\text { and the level of the public and social acceptance as well as desirability } \\
\text { of the IRVs by farmers. }\end{array}$ \\
\hline
\end{tabular}

Adapted from Hekkert et al. (2007)

\section{METHODOLOGY}

\subsection{Study Area}

The study was carried out in the Eastern Zone of Tanzania (EZoT), which comprises four administrative regions: Morogoro, Tanga, Coast, and Dar es Salaam. The zone is generally a tropical area with reliable rainfall averaging from 875 to $1,688 \mathrm{~mm}$ annually, and a mean annual temperature which varies from $18^{\circ} \mathrm{C}$ to $32^{\circ} \mathrm{C}$. This climatic condition is favourable for rice production. Specifically, the study was carried out in EZoT because: firstly, it is one of the leading areas in rice production in Tanzania. Secondly, there are several agricultural research institutes such as Kilombero Agricultural Training and Research Institute (KATRIN) and Cholima Agro-scientific Research Centre that engages in the breeding of different rice varieties. Thirdly, the presence of Sokoine University of Agriculture (SUA), Mkindo Farmers Training Centre (MFTC), and the Ministry of Agricultural Training Institute (MATI) Ilonga established to provide agricultural training. Finally, the presences of many international and local non-Government organizations (NGOs) promote the use of IRVs and their production package in the area.

\subsection{Research Design and Sampling Procedures of actors}


This study employed a convergent parallel mixed method design. This research design involves collecting both quantitative and qualitative data at one site at roughly the same time, and assessing information using parallel constructs for both types of data. The design also involves separately analysing both types of data and comparing the results through procedures such as a side-by-side comparison in a discussion, and jointly displaying both forms of data (Wisdom and Creswell, 2013).

The sampling of actors was done according to their nature and type. Simple random sampling technique was used to select 340 household heads of smallholder rice farmers in four villages namely Mkula (Kilombero), Mkindo (Mvomero), Visezi (Chalinze), and Jitengeni (Korogwe). The villages were deliberately selected from among the rice production District Councils in the EZoT. The villages were chosen because they represented areas where IRVs produced by research institutes were grown. With the help of Village Executive Officers and extension agents, the researcher established a list of households of rice farmers for sampling frame in each village. The sample size was determined using the formula suggested by Kothari (2004) as follows.

$$
\mathrm{n}=\frac{\mathrm{Z}^{2} \mathrm{pqN}}{\mathrm{e}^{2}(\mathrm{~N}-1)+\mathrm{Z}^{2} \mathrm{pq}}=\frac{(1.96)^{2} \times 0.5 \times 0.5 \times 3,040}{(0.05)^{2}(3,040-1)+(1.96)^{2} \times 0.5 \times 0.5}=340.37 \approx 340
$$

Where: $\mathrm{n}=$ sample size needed, $\mathrm{N}=$ the population size of smallholder rice farmers' households, $\mathrm{Z}=z$ score of confidence level, $\mathrm{e}=$ level of precision, and $\mathrm{pq}=$ variance of hypothesized proportion.

Subsequently, the selection of other actors was done using two approaches. First, a reputational approach (Saint Ville, Hickey. and Phillip, 2017), where key informants in research institutes, District Agricultural Irrigation and Cooperative Officers (DAICOs) in the four selected district councils and leaders of farmers' cooperatives/groups were consulted to develop a list of actor groups working in IRVs innovations. Secondly, during interviews, the researcher used a snowball sampling approach, which involved asking each respondent to identify other actor groups involved in IRVs innovations in the EZoT. Subsequently, 13 major actor groups (Table 2) were identified and categorized to reflect similarities in function, common goals, and joint action around IRVs innovation activities. Finally, 99 representatives were purposively selected from these 13 actor groups (Table 2).

Table 2 Respondents from different categories of actor groups

\begin{tabular}{|l|l|l|l|l|l|l|l|}
\hline & \multicolumn{5}{|c|}{ Sampled participants per operational level } \\
\hline S/N & Actor & Village & Ward & District & Zonal & National & Total \\
\hline 1 & $\begin{array}{l}\text { Policy makers from DPP in } \\
\text { Ministry of Agriculture } \\
\text { (MoA) }\end{array}$ & & & & & 5 & 5 \\
\hline
\end{tabular}




\begin{tabular}{|l|l|l|l|l|l|l|l|}
\hline 2 & Research institutes/centres & & & & 7 & & 7 \\
\hline 3 & Seed multiplication agencies & & & & 10 & & 10 \\
\hline 4 & TOSCI & & & & & 3 & 3 \\
\hline 5 & NGOs & & & 6 & & & 6 \\
\hline 6 & $\begin{array}{l}\text { Agricultural training } \\
\text { institutes }\end{array}$ & & & 5 & & & 5 \\
\hline 7 & District councils & & & 14 & & & 14 \\
\hline 8 & Financial institutions & & & 7 & & & 7 \\
\hline 9 & Extension field staff & 5 & 2 & & & & 7 \\
\hline 10 & Rice traders & 10 & & & & & 10 \\
\hline 11 & Agro- input dealers & 4 & & & & & 4 \\
\hline 12 & Rice millers/processors & 9 & & & & & 9 \\
\hline 13 & Farmer cooperatives/groups & 12 & & & & & 12 \\
\hline Total & & $\mathbf{4 0}$ & $\mathbf{2}$ & $\mathbf{3 2}$ & $\mathbf{1 7}$ & $\mathbf{8}$ & $\mathbf{9 9}$ \\
\hline
\end{tabular}

\subsection{Data Collection}

Face to face interviews were conducted to obtain both quantitative and qualitative data about actors' roles from 340 household heads of smallholder rice farmers and 99 other respondents from the 13 actors groups (Table 2). The information captured through interviews was factchecked and corroborated with information from Focus Group Discussions (FGDs) and documentary review methods. Four FGDs (one in each village) were conducted using a pretested interview guide that focused on identifying actors and their functions in IRV innovations. Each FGD was composed of between 6 and 12 smallholder rice farmers. Finally, scholarly publications such as books, journal papers, theses/dissertations, government publications among others were reviewed and summarized into key points and issues. These documents were collected from government authorities, TARI centres, relevant official websites and Sokoine National Agricultural Library (SNAL).

\subsection{Data Analysis}

Quantitative data, which were in categorical form and multiple responses, were analysed by descriptive statistics (frequencies and percentages) and inferential statistics (Chi-square) using SPSS version 20. Qualitative data such as opinions, views, and explanations were analysed using content analysis approach by transcribing, developing coding categories and determining trends of the responses and thereafter interpreting them accordingly.

\section{RESULTS AND DISCUSSION}

The analysis of the actors and their functions was critical in understanding the functioning of the IRVIS. Actors' roles in IRVIS were categorized and discussed based on the functions of IS developed by Hekkert et al. (2007) (Table 1). 


\subsection{Improved Rice Varieties Development}

Information from interviewees in research institutes showed that KATRIN, Cholima AgroScientific Research Centre and SUA are the key actors were playing the role of IRVs generation. KATRIN and Cholima were working in close partnership with Africa Rice Centre and International Rice Research Institute. Similarly, development partners such as United States Agency for International Development (USAID), Japan International Cooperation Agency (JICA) and the World Bank and the Government of Tanzania were also involved in IRVs generation through providing research funds. The involvement of these foreign research institutes and development partners is in line with the objective of the Research and Development Policy (URT, 2010), and ASDS II 2016/2017 - 2024/2025 (URT, 2016) of enhancing collaboration with foreign research institutes of upgrading the level of research and researchers and raise research funds. Similarly, Ecuru (2013) in Uganda reported the collaborations between local researchers and their counterparts abroad appears to be stronger, and partners abroad provided training opportunities for local researchers to enhance their skills and are also seen as a gateway to international research funding sources.

Interviewees from research institutes and Tanzania Official Seed Certification Institute (TOSCI) mentioned TOSCI as being among the key actors that had the primary role in the development of IRVs. The Seed Act No. 18 of 2003 and its Regulations (2007), amended in 2017, put in place procedures and standard which are required to be followed in the process of variety testing, release and registration. Section 10 (1) in Part II of the Seed Act (2003) established TOSCI as an authority to carry out variety performance tests. Under the system, locally bred varieties undergo two distinctness, uniformity, and stability (DUS) tests and the National Performance Trials (NPT). The varieties, which are released in other Eastern African countries whose seed systems are harmonized with those of Tanzania, need only one season of verification before being registered (ESAFF, 2013). NPT is performed to evaluate the value of cultivating and using of varieties. Any new variety should possess an added value over the existing commercial varieties in particular high performance in the following aspects: high yields, resistant to pest and diseases, early maturity, drought tolerance, nutrient content and any other added value.

Seed Regulations 2007 established the NPT Technical Committee (NPT-TC) which reviews reports (results) on NPT, and makes recommendations. NPT-TC secretary reports the results to the applicant and presents recommendations of NPT-TC to the National Variety Release Committee (NVRC). The NVRC reviews the recommendations of the NPT-TC and advises the National Seed Committee (NSC). NSC approves the new varieties and the minister responsible for agriculture publishes in the Government gazette. Once a new variety is approved by Minister, the Director Responsible for development shall register the variety and issue certificate of registration to the applicant. 
However, on the other hand, the study findings revealed limited participation of farmers in IRVs development. The majority (95.0\%) of interviewed farmers reported to have not been participating in the IRVs development by research institutes and SUA. Similarly, all the interviewed agro-dealers, millers, and traders reported not to have participated in IRVs development. This is contrary to the requirements of IS perspectives, which stipulate that if research institutes are to develop technologies that resource-poor farmers can adopt, then it should be designed and implemented through the involvement of all key actors. As emphasized by Rwambali (2012), if the technology is developed under the IS approach, it is possible for researchers to incorporate the concerns of other actors in the system and, thus, increase the chances of technology utilization. Studies (e.g. Abate, Shiferaw, Gebeyehu, Amsalu, Negash and Assefa,, 2011; Bayissa, 2015) show that technologies, which are developed with limited participation of farmers, are not usually relevant to farmers since there is little opportunity to consider the agro-ecological circumstances and socio-economic realities of the end-users.

\subsection{Entrepreneurial Activities in IRVIS}

Results in Table 3 reveal that only $17.3 \%$ of farmers used quality-certified seed of IRVs, $12.1 \%$ of them obtained from Agricultural Seed Agency (ASA) and 5.2\% from research institutes (e.g. KATRIN and Cholima Agro-scientific Research Centre). This implies that there were very few farmers as entrepreneurs who used quality-certified seed of IRVs. Similarly, only ASA and research institutes were identified by farmers to have been undertaking the entrepreneurial activity of producing quality seeds in the study area. Consequently, the study noted that qualitycertified seed multiplication and selling was not yet formalized as the core role of research institutes. A similar observation was made by Mgumia (2015) who found that seed multiplication is not a core function of the research institutes except where necessary as an embedded activity and/or a complement to their principal goals, subject to the availability of resources.

Table 3 Type and source of inputs used in rice production in the EZ $(n=340)$

\begin{tabular}{|c|c|c|c|c|c|c|c|c|c|c|}
\hline \multirow[b]{3}{*}{ Sources of Inputs } & \multicolumn{10}{|c|}{ Type of Inputs Used } \\
\hline & \multicolumn{2}{|c|}{ Seed } & \multicolumn{2}{|c|}{ Fertilizer } & \multicolumn{2}{|c|}{ Pesticides } & \multicolumn{2}{|c|}{ Herbicides } & \multicolumn{2}{|c|}{$\begin{array}{l}\text { Farm } \\
\text { implements }\end{array}$} \\
\hline & $\mathbf{n}$ & $\%$ & $\mathbf{n}$ & $\%$ & $\mathbf{n}$ & $\%$ & n & $\%$ & $\mathbf{n}$ & $\%$ \\
\hline Farmer cooperatives & 0 & 0.0 & 0 & 0.0 & 0 & 0.0 & 0 & 0.0 & 172 & 43.5 \\
\hline ASA & 44 & 12.1 & 0 & 0.0 & 0 & 0.0 & 0 & 0.0 & 0 & 0.0 \\
\hline Research institutes & 19 & 5.2 & 0 & 0.0 & 0 & 0.0 & 0 & 0.0 & 0 & 0.0 \\
\hline $\begin{array}{l}\text { Private service } \\
\text { providers }\end{array}$ & 0 & 0.0 & 0 & 0.0 & 0 & 0.0 & 0 & 0.0 & 195 & 49.4 \\
\hline Agro-dealers & 0 & 0.0 & 266 & 100 & 295 & 100 & 236 & 100 & 0 & 0.0 \\
\hline Own & 301 & 82.7 & 0 & 0.0 & 0.0 & 0.0 & 0 & 0.0 & 28 & 7.1 \\
\hline
\end{tabular}


Besides, findings in Table 3 indicate that agro-dealers were still not yet dealing with entrepreneurial activity of selling the quality - certified seeds of IRVs. Farmers in FGDs in all study villages suggested that agro-dealers should also sell quality seed of IRVs in the villages to boost their availability. Moreover, results in Table 3 indicate that farmer cooperatives $(43.5 \%)$ and individual farmers $(49.4 \%)$ were the other actors who acted as entrepreneurs of renting modern farm implements (tractors, harrows, combine harvesters and pull-pad threshers) as among the production package of IRVs to smallholder rice farmers.

Interviewees from ASA, TOSCI and research institutes identified TANSEED International Ltd as a private company that was also multiplying and selling the quality seeds of IRVs to farmers. Furthermore, DAICOs and District agricultural officers (DAOs) identified Quality Declared Seed (QDS) producers as among the key players of producing quality rice seeds. QDS producers are smallholder rice farmers who are selected, trained, and registered in groups or individually to produce seeds on their farms (not more than 5 acres) under the supervision of local government quality experts (URT, 2009; ESAFF, 2013), with an occasional inspection by TOSCI. However, as indicated in Table 3 no interviewed farmers mentioned TANSEED International Ltd and QDS producers as their sources of quality rice seeds. The fact of this was explained by the interviewees from TANSEED International Limited that their company lacked financial resources and hence it had low coverage in selling quality-certified seed. One interviewee from the company said:

"Our company had not reached many villages including the villages you visited. ...it is true that farmers in those villages had not received the service of our company."

On the other hand, QDS producers had almost ceased to produce seed of IRVs. The interviewed QDS producers reported numerous discouraging factors hampering them. These included costs of production that involved Tsh. 50,000/acre for farm preparation; Tsh. 80,000/acre for planting; Tsh. 100,000/acre for farm levelling; Tsh. 40,000/acre for first weeding; and Tsh. 40,000/acre for second weeding. Unfortunately, some farmers were a bit jealous and disrespected QDS producers. One QDS producer in Mkula village was quoted saying:

"Some farmers disrespect us... they always ignore us, saying that we cannot produce quality seed ... their words spread over the village and discourage many farmers to buy our seeds. They want seeds from ASA, research institute, private companies and should have a label of TOSCI. Ours have no such label and farmers view it to be no different to theirs. This led us not to sell our seeds, and hence stopped producing them."

The findings revealed the low capability of ASA in the multiplication and distribution of the seeds. One of the interviewees from ASA cited the inability of their marketing manager to facilitate the production and distribution of quality seed of IRVs. He had this to say:

"Inadequate availability of quality-certified seeds of IRVs in many areas has been attributed to the inability of ASA marketing manager to perform his role. That is why he has been forced to step down from his position. We are currently having a new marketing manager whom we 
believe will improve the multiplication and availability of the seeds. During the coming few months, we expect the quality-certified seed to be available in many areas."

Moreover, participants in FGDs in four study villages revealed that quality-certified seeds were sold at high price ranging from Tshs 2000 - 2500 per kilogram due to their limited availability. This challenge forced many farmers to use saved or recycled seeds that were easily available at a low cost of Tshs $600-1200$ per kg. Results in Table 3 show that about $82.7 \%$ of farmers were using their own saved seeds. Similar findings were reported in a study by Monela (2014) in Mbeya and Morogoro Regions, that $53.5 \%$ of smallholder farmers did not access quality seeds due to their limited availability and lack of a well-established network of agro-dealers.

\subsection{Diffusion and promotion of IRVs}

According to the IS function's framework, distribution and/or sharing of information is the essential function of the network system. Study findings in Table 4 indicate that $78.8 \%$ and $63.5 \%$ of farmers were getting information on IRVs from their fellow farmers and extension workers respectively. The rest few indicated to have been obtaining such information from farmer cooperatives, MATI Ilonga and MFTC, KATRIN and Cholima centre, international and national NGOs and village leaders and ASA (Table 4). The findings indicate the fact that there were a variety of sources of information on IRV for farmers in the IRVIS which is a positive aspect as far as ISs are concerned.

Table 4 Sources of information on IRVs from actors $(n=340)$

\begin{tabular}{|c|c|c|c|c|c|c|c|}
\hline \multirow[b]{2}{*}{ Actors } & \multirow[b]{2}{*}{ 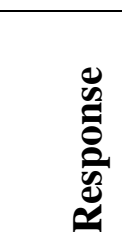 } & \multicolumn{3}{|c|}{ Type of Production System } & \multirow[b]{2}{*}{ Total } & \multirow[b]{2}{*}{$\chi^{2}$} & \multirow[b]{2}{*}{ p - value } \\
\hline & & Rain-fed & Irrigation & $\begin{array}{l}\text { Rain-fed } \\
\text { and } \\
\text { irrigation }\end{array}$ & & & \\
\hline \multirow{3}{*}{$\begin{array}{l}\text { KATRIN and } \\
\text { Cholima centre }\end{array}$} & Yes & $8(7.2)$ & $191(5.8)$ & $18(16.5)$ & $45(13.2)$ & & \\
\hline & No & $103(92.8)$ & $101(84.2)$ & $91(83.5)$ & $295(86.8)$ & & \\
\hline & Total & $111(100)$ & $120(100)$ & $109(100)$ & $340(100)$ & 5.238 & $0.073 \mathrm{n} . \mathrm{s}$ \\
\hline \multirow[t]{3}{*}{ MATIs } & Yes & $12(10.8)$ & $29(24.2)$ & $25(22.9)$ & $66(19.4)$ & & \\
\hline & No & $99(89.2)$ & $91(75.8)$ & $84(77.1)$ & $274(80.6)$ & & \\
\hline & Total & $111(100)$ & $120(100)$ & $109(100)$ & $340(100)$ & 7.849 & $0.02 *$ \\
\hline \multirow[t]{3}{*}{ Extension } & Yes & $48(43.2)$ & $97(80.8)$ & $71(65.1)$ & $216(63.5)$ & & \\
\hline & No & $63(56.8)$ & $23(19.2)$ & $38(34.9)$ & $124(36.5)$ & & \\
\hline & Total & $111(100)$ & $120(100)$ & $109(100)$ & $340(100)$ & 35.345 & $0.000 *$ \\
\hline \multirow[t]{3}{*}{ ASA } & Yes & $0(0)$ & $3(2.5)$ & $2(1.8)$ & $5(1.5)$ & & \\
\hline & No & $111(100)$ & $117(97.5)$ & 107(98.2) & $335(98.5)$ & & \\
\hline & Total & $111(100)$ & $120(100)$ & $109(100)$ & $340(100)$ & & \\
\hline \multirow{2}{*}{$\begin{array}{l}\text { Farmer } \\
\text { Cooperatives }\end{array}$} & Yes & $10(9.0)$ & $49(40.8)$ & $35(32.1)$ & $94(27.6)$ & & \\
\hline & No & 101(91.0) & $71(59.2)$ & $74(67.9)$ & $246(72.4)$ & & \\
\hline
\end{tabular}




\begin{tabular}{|l|l|l|l|l|l|l|l|}
\hline & Total & $111(100)$ & $120(100)$ & $109(100)$ & $340(100)$ & 30.792 & $0.000^{*}$ \\
\hline \multirow{3}{*}{$\begin{array}{l}\text { Fellow } \\
\text { Farmers }\end{array}$} & Yes & $88(79.3)$ & $88(73.3)$ & $92(84.4)$ & $268(78.8)$ & & \\
\cline { 2 - 9 } & No & $23(20.7)$ & $32(26.7)$ & $17(15.6)$ & $72(21.2)$ & & \\
\cline { 2 - 9 } & Total & $111(100)$ & $120(100)$ & $109(100)$ & $340(100)$ & 4.214 & 0.122 n.s. \\
\hline \multirow{4}{*}{ Village leaders } & Yes & $7(6.3)$ & $8(6.7)$ & $9(8.3)$ & $24(7.1)$ & & \\
\cline { 2 - 9 } & No & $104(93.7)$ & $112(93.3)$ & $100(91.7)$ & $316(92.9)$ & & \\
\cline { 2 - 9 } & Total & $111(100)$ & $120(100)$ & $109(100)$ & $340(100)$ & 0.362 & $0.834 n . s$. \\
\hline \multirow{3}{*}{ NGOs } & Yes & $7(6.3)$ & $14(11.7)$ & $8(7.3)$ & $29(8.5)$ & & \\
\cline { 2 - 9 } & No & $104(93.7)$ & $106(88.3)$ & $101(92.7)$ & $311(91.5)$ & & \\
\cline { 2 - 8 } & Total & $111(100)$ & $120(100)$ & $109(100)$ & $340(100)$ & 2.415 & $0.299 n . s$. \\
\hline
\end{tabular}

NB: *Significance at 5\%, and n.s. = Not significant

Likewise, the results in Table 4 indicate that promotion of IRVs was high to farmers who practised irrigated farming system compared to farmers who were rain-fed dependants and the difference was statistically significant $(p \geq 0.05)$ from MATIs, extension agents and farmers cooperatives. This implies that many farmers who depended on irrigated farming system had higher access to information of IRVs as opposed to farmers who depended on rain-fed fields. This was further evidenced by the fact that all farmers in irrigation schemes of Mkula, Mkindo, Visezi and Mombo were planting IRVs especially TXD 306 (SARO 5). According to interviewees from farmer cooperatives, the adoption of TXD 306 in irrigation schemes was also facilitated by the established by-laws. All farmers in irrigation schemes were compelled to use the recommended IRVs. However, as noted earlier in the proceeding section, most of them used saved or recycled seeds of IRVs.

Moreover, interviewees from research institutes, agricultural training institutes and ASA revealed that different communication and knowledge sharing methods were used to promote and disseminate the IRVs (Table 5). They indicated that interactive methods like seminars, workshops, short and long term training, farmer field school (FFS), joint demonstration plots and agricultural shows were used and seemed to be more effective in imparting knowledge on IRVs and for getting feedback from users. However, the methods were viewed as not effective to speed the spread of IRVs because such events only involved those who are selected as representatives to attend these events. Also information from farmers revealed that the selection of representatives was done only from members of farmers' cooperatives. Worse still the selection was allegedly based on favouritism and always leaders of cooperatives selected themselves.

Table 5 Actors and their strategies of promoting and creating awareness on IRVs

\begin{tabular}{|l|l|l|}
\hline Actor & Role & Method \\
\hline KATRIN, & Provide training on IRVs and & $\begin{array}{l}\text { Seminars, workshops, Joint } \\
\text { Cholima Centre } \\
\text { and SUA }\end{array}$ \\
$\begin{array}{l}\text { preparing extension booklets and } \\
\text { materials. }\end{array}$ & $\begin{array}{l}\text { agricultural shows, television, } \\
\text { radio and internet. }\end{array}$ \\
\hline
\end{tabular}




\begin{tabular}{|c|c|c|}
\hline & & $\begin{array}{l}\text { Pathways: extension agents, seed } \\
\text { multipliers, farmer cooperatives, } \\
\text { village leaders, and progressive } \\
\text { farmers. }\end{array}$ \\
\hline $\begin{array}{l}\text { MFTC and MATI } \\
\text { Ilonga }\end{array}$ & $\begin{array}{l}\text { Training of farmers and extension } \\
\text { staff. }\end{array}$ & $\begin{array}{l}\text { Short- and long-term training, } \\
\text { seminars, FFS. }\end{array}$ \\
\hline Extension & $\begin{array}{l}\text { Providing advisory services on } \\
\text { IRVs. }\end{array}$ & $\begin{array}{l}\text { Residential training. } \\
\text { On-farm trials/demonstration plots }\end{array}$ \\
\hline ASA & $\begin{array}{l}\text { Promotion and marketing the } \\
\text { quality seeds of IRVs. } \\
\text { Preparing extension training } \\
\text { manuals. }\end{array}$ & $\begin{array}{l}\text { Joint demonstration plots, FFS, } \\
\text { seminar, and workshops. } \\
\text { Media: radio, Televisions, phones, } \\
\text { brochures, poster/leaflets, booklets, } \\
\text { and manual. } \\
\text { Pathways: extension agents, } \\
\text { progress farmers and private } \\
\text { companies. }\end{array}$ \\
\hline RIPOMA & $\begin{array}{l}\text { Training farmers on IRV and } \\
\text { their production package }\end{array}$ & $\begin{array}{l}\text { Demonstration plots, FFS and } \\
\text { media }\end{array}$ \\
\hline $\begin{array}{l}\text { JICA, World } \\
\text { Bank and USAID. }\end{array}$ & $\begin{array}{l}\text { Funding dissemination activities. } \\
\text { Supporting agro skill } \\
\text { development at Mkindo, Mombo } \\
\text { and CHAURU irrigation } \\
\text { schemes. } \\
\text { Training lead farmers obliged to } \\
\text { train other farmers in their } \\
\text { respective villages or schemes. }\end{array}$ & $\begin{array}{l}\text { Pathways: SUA, MFTC, and } \\
\text { MATI Ilonga, KATRIN and } \\
\text { Cholima Agro-Scientific Research } \\
\text { Centre and ASA. }\end{array}$ \\
\hline MoA & $\begin{array}{l}\text { Funding dissemination activities. } \\
\text { Farmers' training. }\end{array}$ & $\begin{array}{l}\text { Pathway: SUA, MFTC and MATI } \\
\text { Ilonga, KATRIN, Cholima Centre, } \\
\text { Africa RISING - NAFAKA, and } \\
\text { ASA. }\end{array}$ \\
\hline $\begin{array}{l}\text { Aga Khan } \\
\text { Foundation }\end{array}$ & Training farmers on IRVs & Seminars and workshops. \\
\hline $\begin{array}{l}\text { Yara Tanzania } \\
\text { Limited }\end{array}$ & $\begin{array}{l}\text { Training farmers on the } \\
\text { application of Yara fertilizer on } \\
\text { IRVs. }\end{array}$ & $\begin{array}{l}\text { Brochures, seminars, workshops, } \\
\text { and demonstration plots. }\end{array}$ \\
\hline Fellow farmers & Growing rice & Observation, and informal meeting \\
\hline
\end{tabular}

Similarly, interviewees from research institutes, agricultural training institutes and ASA revealed the use of ICT such as television, radio, phone, internet through agricultural portals, and printed materials. But it was acknowledged to have been rarely used because farmers had not yet fully been connected to these ICT facilities. In this connection, they viewed media and printed materials to have a low speed of spreading the IRVs. Media become effective in 
spreading information in the areas where farmers are well connected to communication and other infrastructures such as electricity and roads.

\subsection{Guidance of the Search for IRVs}

Any innovation normally undergoes shaping and reshaping as areas of improvement are identified and worked on to make the modified innovation more useful. Therefore, guidance of the search refers to areas of an innovation that are identified as needing further investment for improvement. In this connection, KATRIN and Cholima centre were found to be among the key actors involved in this activity. All interviewees from KATRIN and Cholima centre reported to be working with farmers and actors involved in the promotion, dissemination, and use of IRVs (Table 5) to get feedback on IRV innovations. On the open-ended question "what your motive for has been generating or modifying rice varieties," interviewed researchers mentioned various drivers. Examples include feedback from farmers, curiosity, national agenda, researchers' perception of the existing problem, and donors' priorities, among others.

However, as noted earlier, $95.0 \%$ of the interviewed farmers reported not to have been contacted by researchers for identifying areas for improvement of IRVs. It was pointed out that those who have been involved are selected from farmers' cooperatives in irrigation schemes as representatives. Farmers who were not members of farmers' cooperatives could not recognize such representation. Consequently, most members of farmers' cooperatives did not recognise such representation as they reported it to have been done based on nepotism and in most times leaders selected themselves to participate. Similarly, agro-dealers, rice millers, and traders reported to have not participated in this activity. From these findings, it was realized that there is fundamental gap between research and farmers who are the main end-users of the innovation in the system. Researchers relied on information not directly from individual farmers, but from leaders of farmers' cooperatives who were in relationship of mistrust with their fellow farmers.

\subsection{Market Formation for IRV Produce}

While the NRDS (URT, 2009) and ASDP II 2016/2017 - 2024/2025 (URT, 2016) in which IS concepts are anchored insist to commercialize rice production by improving and expanding internal and external markets in line to TDV 2025, results of this study indicated the limited organized rice marketing system in the study area. Many of the interviewed farmers in all four villages $(66.8 \%)$ were selling their rice at the farm gate and marketed the rice in raw form with little value addition (Table 6).

Table 6 Buyers of rice in the EZoT $(n=340)$

\begin{tabular}{|l|l|l|l|l|l|}
\hline \multicolumn{4}{|l|}{ Village } \\
\hline Marketing place & Mkula & Mkindo & Visezi & Jitengeni & Total \\
\hline Farm gate & $44(12.9)$ & $72(21.2)$ & $66(19.4)$ & $45(13.2)$ & $227(66.8)$ \\
\hline Warehouse of villages or millers & $29(8.5)$ & $3(0.9)$ & $26(7.6)$ & $63(18.5)$ & $121(35.6)$ \\
\hline
\end{tabular}




\begin{tabular}{|l|l|l|l|l|l|}
\hline Local markets & $0(0.0)$ & $1(0.3)$ & $8(2.4)$ & $0(0.0)$ & $9(2.6)$ \\
\hline Nearby Urban Market & $0(0.0)$ & $0(0.0)$ & $3(0.9)$ & $1(0.3)$ & $4(1.2)$ \\
\hline
\end{tabular}

Nevertheless, most quantity of rice was marketed during the harvesting season between May and July when the price is low. Results also revealed the limited market actors like domestic and international wholesalers or exporters in the study area. Many interviewed farmers $(71.5 \%)$ reported having sold the rice to middlemen. The rest few also sold their rice directly to local seasonal traders, farmers, local millers and retailers (Table 7).

Table 7 Marketing place of rice in the study area $(n=340)$

\begin{tabular}{|l|l|l|l|l|l|}
\hline \multicolumn{7}{|l|}{ Village } \\
\hline Actor & Mkula & Mkindo & Visezi & Jitengeni & Total \\
\hline Middlemen & $59(17.4)$ & $59(17.4)$ & $72(21.2)$ & $53(15.6)$ & $243(71.5)$ \\
\hline Local seasonal traders & $8(2.4)$ & $21(6.2)$ & $23(6.8)$ & $63(18.5)$ & $115(33.8)$ \\
\hline Farmers (rural consumers) & $3(0.9)$ & $14(4.1)$ & $15(4.4)$ & $5(1.5)$ & $37(10.9)$ \\
\hline Local millers & $10(2.9)$ & $18(5.3)$ & $0(0.0)$ & $1(0.3)$ & $29(8.5)$ \\
\hline Retailers & $0(0.0)$ & $0(0.0)$ & $2(0.6)$ & $8(2.4)$ & $10(2.9)$ \\
\hline
\end{tabular}

The findings indicate that market for the paddies of IRVs innovations was not yet created. Farmers continued to depend on the networks of local agents of seasonal traders, millers and retailers who tend to exploit them in selling their rice. Equally, farmers were not in a good position to negotiate for better prices because middlemen controlled the available informal markets in the villages. During FGDs, farmers admitted that, when wholesalers and exporters bought rice directly from the farmers, the farmers got better prices than they did from middlemen. Hence, farmers agreed that participation of wholesalers and exporters was important to guarantee better prices and reliable markets. The major concern of farmers was for the government to create enabling environment for wholesalers and exporters to buy rice directly from farmers, so to speak. Subsequently, for the problem of buying by volume using overfilled bags as has been one of the requirements of middlemen, farmers suggested that the government should intervene and declare un-milled rice to be sold by weight.

\subsection{Financial Resource Mobilization for Farmers to Invest in IRVs}

Financial infrastructures such as subsidies, grants, banks, micro-finance institutions, among others are the most important sources of capital for investing and implementing IRVs. Results in Table 8 indicate that many farmers in all study villages $(58.2 \%)$ did not take any credit in 2016/2017 production season. Out of these, $9.4 \%, 10.0 \%, 12.9 \%$ and $24.1 \%$ were from Mkula, Mkindo, Visezi and Jitengeni, respectively. In other words, less than half $(41.2 \%)$ of interviewed heads of households of smallholder rice farmers accessed credit for investing on IRVs. Out of these, $10.3 \%, 8.8 \%, 6.8 \%, 5.6 \%, 5.3 \%, 4.4 \%$ and $0.6 \%$ indicated to obtain their credit from local business people, Village Community Banks (VICOBA), fellow farmers, Tanzania Agricultural Development Bank (TADB), Vision Fund Tanzania, and savings and 
credit cooperative societies (SACCOS), and Private Agricultural Sector Support (PASS) Trust respectively (Table 8).

Table 8 Source and money by smallholder rice farmers $(n=340)$

\begin{tabular}{|l|l|l|l|l|l|}
\hline & & Village & & & \\
\hline Actors & Mkula & Mkindo & Visezi & Jitengeni & Total \\
\hline Local businesspeople & $4(1.2)$ & $10(2.9)$ & $16(4.7)$ & $5(1.5)$ & $35(10.3)$ \\
\hline VICOBA & $5(1.5)$ & $18(5.3)$ & $4(1.2)$ & $3(0.9)$ & $30(8.8)$ \\
\hline Fellow Farmers & $4(1.2)$ & $3(0.9)$ & $11(3.2)$ & $5(1.5)$ & $23(6.8)$ \\
\hline TADB & $19(5.6)$ & $0(0.0)$ & $0(0.0)$ & $0(0.0)$ & $19(5.6)$ \\
\hline Vision Fund Tanzania & $0(0.0)$ & $0(0.0)$ & $18(5.3)$ & $0(0.0)$ & $18(5.3)$ \\
\hline SACCOS & $2(0.6)$ & $1(0.3)$ & $5(1.5)$ & $7(2.1)$ & $15(4.4)$ \\
\hline PASS & $0(0.0)$ & $2(0.6)$ & $0(0.0)$ & $0(0.0)$ & $2(0.6)$ \\
\hline Did not take any credit & $32(9.4)$ & $40(10.0)$ & $44(12.9)$ & $82(24.1)$ & $198(58.2)$ \\
\hline Total & $\mathbf{6 6}(\mathbf{1 9 . 4})$ & $\mathbf{7 4 ( 2 1 . 8 )}$ & $\mathbf{9 8}(\mathbf{2 8 . 8})$ & $\mathbf{1 0 2}(\mathbf{5 . 9})$ & $\mathbf{3 4 0}(\mathbf{1 0 0 . 0})$ \\
\hline
\end{tabular}

Information from FGDs revealed that most farmers who obtained loans from local businesspeople and their fellow farmers repaid their loans in terms of rice produce. For a loan of Tshs 40,000 to Tshs 45,000 the farmer would repay with an $80-100 \mathrm{~kg}$ bag of rice, but eventually the same amount of rice would be sold for Tshs 80,000 to Tshs 150,000. Farmers were therefore unhappy with this credit modality because of its exploitative nature.

Study findings in Table 8 also reveal that TADB had provided loans to some rice farmers in Mkula village only in the 2016/2017 production season. Other farmers in Mkindo, Visezi, and Jitengeni villages were merely promised loans in the 2015/2016 production season by the Bank. Farmers in FGDs reported that TADB was the only bank that was appointed by the Government of Tanzania to provide loans to smallholder farmers at low interest rates. However, the bank had not performed satisfactorily. The unsatisfactory performance of TADB was further noted by the President of the URT, John Pombe Magufuli when he said:

"TADB Bank was founded in 2014 and given a capital of Tshs 60 billion and later increased to Tshs 103.77 billion borrowed by the Government from the African Development Bank $(A f D B)$ as part of Tshs 207.55 billion. Let me be honest and realistic, I am still not satisfied with the performance of the Agricultural Bank. The provision of loans to smallholder farmers has not been done satisfactorily, instead the Bank has been lending to other banks" (Mwananchi newspaper of Tuesday, 31st July 2018).

However, during the interview, officers from TADB blamed farmers for not adhering to the conditions of the TADB. One officer said:

"We lend farmers with interest rate ranging from 8 - 12 percent and allow them to use leasehold land as collateral through organizing farmers into groups. However, the challenge is most farmers are landless and not ready to form groups or store their harvest in the 
warehouse and call us to sell together when the price increases for them to repay their loans... but they are good in complaining before national leaders."

Besides, information from the National Microfinance Bank (NMB) Branch Manager in Mombo revealed that the NMB as a business-oriented company was ready to provide loans to individual smallholder rice farmers. However, its readiness was constrained, among others, by the farms being rain-fed, uncertain markets and fluctuating prices, and lack of collateral among smallholder rice farmers. A loan officer from Turiani NMB had this to say:

"We have had a very difficult time to lend to rice farmers. What is most troubling is that many farmers lack collateral and are dependent on rain-fed fields. Also, lending to farmers through groups is still problematic... for the bank to lend to farmers groups there must be a tripartite agreement between three actors: the bank, businessman, and the farmer. The businessperson must agree to buy the farmers' crop for the price they will agree. Often traders refuse to enter into this kind of contract due to rice market uncertainty."

The findings show further that PASS in collaboration with CRDB Bank was offering financial services to individuals or groups of rice farmers, especially in irrigation schemes. However, from the survey, only $0.6 \%$ of the interviewed farmers from Mkindo village obtained loans from PASS (Table 8). Information from one officer in PASS indicated that they have been providing this service to rice farmers from 2015 and concentrated more in Dakawa irrigation scheme. Since 2015, the number of rice farmers who have been getting loans at Dakawa irrigation scheme has ranged from between 50 and 70 per year.

Information from FGDs revealed that financial institutions are among the right players for the functioning of the IRVIS. It was indicated that easy access to credit by farmers from credit institutions would have probably enabled them to invest more in quality seed of IRVs and hence increase rice production. According to farmers, lending conditions of the banks and other credit institutions such as PASS and Vision Fund Tanzania are too stringent and complicated for ordinary small farmers to be able to borrow from. At the same time, the available SACCOS were poorly functioning in the villages because of misuse and embezzlement of funds by leaders. The only hope was on local businesspeople in the village, VICOBA, and their fellow farmers. However, most of the farmers depended on their own funds from previous rice sales and petty businesses. Lack of access to credit was identified as a key constraint to smallholder production and served as a barrier against IRVIS. This is, because many smallholder rice farmers simply lacked the money for investing on IRVs. This finding is similar to those of other studies such as Rwambali (2012) in Tanzania, and Lowitt, Hickey, Saint Ville, Raeburn, Thompson-colo'n, Laszlo, and Phillip (2015) in the Caribbean Community, which also showed that most smallholder farmers cannot access funds provided by different institutions due to restrictive regulations. 


\subsection{Creation of legitimacy}

The study found that the function of legitimization of IRVs was performed by the same actors played the role of IRVs diffusion (see section 4.3). With regard to this function, the study further mapped the rise and growth of interest or acceptance of IRVs by farmers. Results in Table 9 indicate that IRVs are socially acceptable as many farmers (54.4\%) during the 2016/2017 production season planted them. Also, as explained earlier in section 4.3, it was noted that IRVs are more adopted by farmers in irrigation schemes, compared to farmer who relied on rain-fed agriculture and the difference was significant $(p<0.05)$. This implies that IRV s have created a stronger legitimacy in irrigation schemes than in rain-fed farms. The IRVs reported to have been grown in the study area included TXD 306 (SARO 5), Super India, Komboka and IR64 (in Kiswahili named as Sina Ubaya to connote 'I don't have blemish'). Equally, TXD 306 was most preferred in all the study villages and it was the current recommended IRVs in the EZoT.

Table 1 Level of Usage of IRVs, fertilizers and agro-chemicals in 2016/2017

\begin{tabular}{|l|l|l|l|l|l|l|}
\hline & $\begin{array}{l}\text { Improved } \\
\text { varieties }\end{array}$ & $\begin{array}{l}\text { Local and } \\
\text { improved }\end{array}$ & $\begin{array}{l}\text { Local } \\
\text { varieties }\end{array}$ & Total & $\begin{array}{l}\text { Chi- } \\
\text { square }\end{array}$ & $\begin{array}{l}\text { p- } \\
\text { value }\end{array}$ \\
\hline Rain-fed agriculture & $27(24.3)$ & $13(11.7)$ & $71(64.0)$ & $111(100)$ & & \\
\hline Irrigated agriculture & $111(92.5)$ & $3(2.5)$ & $6(5.0)$ & $120(100)$ & 154.905 & 0.000 \\
\hline $\begin{array}{l}\text { Rain-fed and } \\
\text { irrigated agriculture }\end{array}$ & $47(43.1)$ & $35(32.1)$ & $27(24.8)$ & $109(100)$ & & \\
\hline Total & $\mathbf{1 8 5 ( 5 4 . 4 )}$ & $\mathbf{5 1 ( 1 5 . 0 )}$ & $\mathbf{1 0 4 ( 3 0 . 6 )}$ & $\mathbf{3 4 0 ( 1 0 0 )}$ & & \\
\hline
\end{tabular}

Through an open-ended question, most farmers reported to have high preference to TXD 306 because of its traits of high yields, aroma and quality grains. A variety TXD 306 has good grain yield qualities despite its late maturity; therefore, incorporating genes for early maturing period would increase the potentiality of acceptance of this cultivar in the study area. This result implies that the farmers' trait preferences should be highly considered during the development of IRVs. In this regard, farmers and market actors' engagement in generation of IRVs, especially at defining research agenda and innovation challenges as well as guidance of the search, is essential to address these concerns for increasing the legitimacy of IRVs.

However, information from FGDs in all the study villages revealed that some farmers still had negative perceptions to IRVs including the TXD 306. Such perception emanated from the high price of quality-certified seed. This once again supports the assertion that we made earlier that the price of quality-certified seeds was more than twice the price of the farmer-saved seed. Therefore, cost of quality certified seed of IRVs should be expeditiously addressed. The Government of Tanzania should put subsidies and tax exemption on quality certified seeds and their production packages for enhancing the legitimacy of IRVs. This is actually one of the aspects that farmers in the FGDs in all study villages thought that, if quality seeds and their 
production packages are subsidized and tax exempted, it could be a solution for increasing adoption of IRVs.

\section{CONCLUSION AND RECOMMENDATIONS}

\subsection{Conclusion}

From the findings, the study concludes that IRVIS had not functioned according to the IS perspectives because of failure of the agro-dealers to deal with quality seed of IRVs, inability of ASA and TANSEED International Ltd in multiplying quality-certified seed of IRVs, and ceasing of QDS producers to produce quality-certified seed of IRVs thereby resulting in low availability and high prices of quality-certified seed of IRVs. Also weak participation of farmers, rice traders and millers in the processes of generating the IRVs has high likelihood of causing generation of IRVs that do not meet the needs of end-users. Moreover, lack of organized formal markets, and high risks, the uncertainty of collateral and high transaction costs for smallholder farmers have limited the extension of financial services to rural areas and have lowered the use of quality-certified seed of IRVs. Hence, while there is high acceptance of IRVs, the use of quality-certified seed in the EZoT remained relatively low. This was evidenced by the study findings which indicated that majority of farmers $(82.7 \%)$ used saved or recycled seeds resulting from weak functioning of IRVIS.

\section{RECOMMENDATIONS}

In light of the findings and conclusion above, the study recommends the following to improve the functions of the IRVIS and hence increase rice production: (1) the Government of Tanzania should take deliberate steps of enhancing participation of farmers, agro-dealers, traders and millers in IRVIS in order to incorporate the farmers' traits of preference during IRVs generation; (2) the government should strengthen the participation of the private companies in multiplication and dissemination of quality seed; (3) the government, through a MoA, should facilitate the link between the farmers and external markets; (4) the government should formalize ownership of the rural land in order to enable farmers to use it as collateral to obtain loans from banks; (5) the government should strengthen rural/community banks and SACCOS to make them responsive to agricultural development financial needs; and (6) there should be an effort to expand the areas under irrigation by establishing new irrigation schemes for smallholder farmers to move away from rain-dependent agriculture, and, therefore, reduce the fear of risks by banks in lending to smallholder farmers.

\section{REFERENCES}

ABATE, T., SHIFERAW, B., GEBEYEHU, S., AMSALU, B., NEGASH, K. and ASSEFA, A. 2011. A systems and partnership approach to agricultural research for development: Lessons from Ethiopia. Outlook Agriculture, 40(3): 213 - 220 
ASENSO-OKYERE, K., DAVIS, K and AREDO, D. 2008. Advancing Agriculture in Developing Countries through Knowledge and Innovation: Synopsis of an International Conference. International Food Policy Research Institute. Washington DC, USA

BAYISSA, D. D. 2015. Investigating key institutional factors affecting the linkage of knowledge institutes with farmers in agricultural research in Ethiopia. American Journal of Human Ecology, (4) 2: 16-32

BERGEK, A., HEKKERT, M., JACOBSSON, S., MARKARD, J., SANDÉN, B. and TRUFFER, B. 2015. Technological innovation systems in contexts: Conceptualizing contextual structures and interaction dynamics. Environ. Innovation Soc. Transitions [viewed on 15 November 2017]. Available from: http://dx.doi.org/10.1016/j.eist.2015.07.003

ECURU, J. 2013. Unlocking Potentials of Innovation Systems in Low Resource Settings. Thesis for Award of PhD Degree at Blekinge Institute of Technology, Karlskrona, Sweden

ESAFF. 2013. A Scoping Study report on Seeds and Agriculture Research Processes in Tanzania: The case of Small Scale Farmers' Participation in Setting Research Agenda Participation. Supported under the EU funded INSARD project

FAGERBERG, J., MOWERY, D. C. and NELSON, R. R. (Eds.). 2005. The Oxford Handbook of Innovation. Oxford University Press, Oxford; New York

HEKKERT, M. P., SUURS, R. A. A., NEGRO, S. O., KUHLMANN, S. and SMITS, R. E. H. M. 2007. Functions of innovation systems: A new approach for analyzing technological change. Technological Forecasting and Social Change, 74(4): 413 - 432

INTARAKUMNERD, P., and CHAMINADE, C. 2007. Strategy versus practice in innovation system policy: The case of Thailand. Asian Journal of Technology Innovation, 15(2): 197-213

JUMA, C. 2011. The New Harvest Agricultural Innovation in Africa. Oxford University Press, Inc., New York

KOTHARI, C. R. 2004. Research Methodology. Methods and Techniques. New Age International Publishers, New Delhi 
LARSEN, K., KIM, R. and THEUS, F. (Ed.). 2009. Agribusiness and Innovation Systems in Africa. The World Bank, Washington, D.C

LOWITT, K., HICKEY, M. G., SAINT VILLE, A., RAEBURN, K., THOMPSON-COLO`N, T., LASZLO, S. and PHILLIP, E. L. 2015. Factors affecting the innovation potential of smallholder farmers in the Caribbean Community. Reg Environ Change, 15: 1367 1377

MAERERE, A. P., RWEYEMAMU, C. L., SIBUGA, K. P., MGEMBE, E. R., RWAMBALI, E. G. and NCHIMBI-MSOLLA, S. 2010. Analysis of the agricultural science, technology and innovation system: Banana (Musa Spp.) case study in Tanzania. Acta Hortculturae, 179: $851-858$

MGUMIA, A. H. 2015. Transformation of agricultural technology development approaches in Tanzania. Thesis for Award of PhD Degree at Sokoine University of Agriculture, Morogoro, Tanzania

MKULA, N. D. 2018. Interaction among Actors and its Influence on Quality Sugarcane Production in Tanzania: A case of Kilombero Outgrowers Sugarcane scheme. Thesis for Award of PhD Degree at Sokoine University of Agriculture, Morogoro, Tanzania

MONELA A. G. 2014. Access to and Adoption of Improved Seeds by Smallholder Farmers in Tanzania: Cases of Maize and Rice Seeds in Mbeya and Morogoro Regions. Dissertation for Award of MA at Sokoine University of Agriculture, Morogoro, Tanzania

RWAMBALI, E. G. 2012. Agricultural technology innovation system: A case of TARP IISUA and Banana research project in Tanzania. PhD Thesis; Sokoine University of Agriculture, Morogoro, Tanzania

SAINT VILLE, S. A., HICKEY M. G. and PHILLIP, E. L. 2017. How do stakeholder interactions influence national food security policy in the Caribbean? The case of Saint Lucia. Food Policy, 68: $53-64$

SIDA. 2015. Support to Innovation and Innovation Systems within the Framework of Swedish Research Cooperation. Innovation Working Group, September $1^{\text {st }}, 2015$. Swedish International Development Cooperation Agency

SPIELMAN, D. J. 2005. Innovation Systems Perspective on Developing Country Agriculture: A Critical Review. Discussion Paper No. 2. International Food Policy Research Institute, Washington DC, USA 
SRI - TANZANIA. 2019. International Network and Resources Center [viewed on 07 April, 2020). Available from: http://sri.ciifad.cornell.edu/countries/tanzania/index.html

SZOGS, A., CUMMINGS, A., and CHAMINADE, C. 2011. Building systems of innovation in less developed countries: The role of intermediate organizations supporting interactions in Tanzania and El Salvador. Innovation and Development, 1 (2): 283 302

TURNER, A. J., KLERKX, L., RIJSWIJK, K., WILLIAMS, T. and BARNARD, T. 2015. Systemic problems affecting co-innovation in the New Zealand Agricultural Innovation System: Identification of blocking mechanisms and underlying institutional logics. NJAS - Wageningen Journal of Life Sciences, http://dx.doi.org/ 10.1016/j.njas.2015.12.001

URT. 1999. The Tanzania Development Vision 2025: Planning Commission [viewed on 13 March 2018]. Available from: http://www.mof.go.tz/mofdocs/overarch/Vision2025.pdf

URT. 2003. The Seeds Act. Dar es Salaam: The government Printer

URT. 2007. The Seeds Regulations. Dar es Salaam: The Government Printer

URT. 2009. National Rice Development Strategy. Ministry of Agriculture Food Security and Cooperatives. Dar es Salaam: The Government Printer

URT. 2013. National Agriculture Policy: Ministry of Agriculture, Food Security and Cooperative. Dar es Salaam: The Government Printer

URT. 2016. Agricultural Sector Development Programme Phase Two (ASDP II). Government Programme Document. Dar es Salaam: The Government Printer

USDA. 2019. United Republic of Tanzania - Grain and Feed Annual Report 2019 Corn, Wheat and Rice [viewed on 28 March 2020]. Available from: https://apps.fas.usda.gov/newgainapi/api/report/downloadreportbyfilename

WIECZOREK, J. A. and HEKKERT, P. M. 2012. Systemic instruments for systemic innovation problems: a framework for policy makers and innovation scholars. ISU Working Paper No.11.08. Science and Public Policy Journal, 39: 74 - 87

WILSON, R. T. and LEWIS, I. 2015. The Rice Value Chain in Tanzania: A report from the Southern Highlands Food Systems Programme. FAO 
S. Afr. J. Agric. Ext.

Vol. 49 No. 1, 2021: 59-80

Charles, Mattee, Msuya

http://dx.doi.org/10.17159/2413-3221/2021/v49n1a10778

(License: CC BY 4.0)

WISDOM, J. and CRESWELL, J. W. 2013. Mixed Methods: Integrating Quantitative and Qualitative Data Collection and Analysis While Studying Patient-Centered Medical Home Models. Rockville, MD: Agency for Healthcare Research and Quality. AHRQ Publication No. 13-0028-EF 